\title{
THE POLITICAL ECONOMY \\ OF LATIN AMERICA
}

IN THE POSTWAR PERIOD 
ILS Critical Reflections on Latin America Series 


\section{The Political Economy of Latin America in the Postwar Period}

Edited by

Laura Randall

$\checkmark$ University of Texas Press, Austin Institute of Latin American Studies 
Copyright $(\subset 1997$ by the University of Texas Press

All rights reserved

Printed in the United States of America

First Edition, 1997

Requests for permission to reproduce material from this work should be sent to Permissions, University of Texas Press, P.O. Box 7819, Austin, Texas 787137819

\section{Library of Congress Cataloging-in-Publication Data}

The political economy of Latin America in the postwar period / edited by Laura Randall.

p. cm. - (ILAS critical reflections on Latin America series) Includes bibliographical references and index.

ISBN 0-292-77086-3 (hardcover : alk. paper). — ISBN 0-292-77083-9 (paperback : alk. paper)

1. Latin America-Economic policy. 2. Latin America-Economic conditions-1945- . I. Randall, Laura. II. Series: Critical reflections on Latin America series.

HC125.P644 1997

$338.98^{\prime} 009^{\prime} 045-\mathrm{dc} 21$

ISBN 978-0-292-75830-8 (e-book)

ISBN 978-0-292-78599-1 (individual e-book) 